\title{
PERANAN FOSFOLIPID DALAM PAKAN PADA PEMIJAHAN DAN PENINGKATAN KUALITAS TELUR IKAN KERAPU BATIK (Epinephelus microdon)
}

\author{
Nyoman Adiasmara Giri, Tony Setiadharma, dan Bejo Slamet
}

\begin{abstract}
ABSTRAK
Penelitian teknologi pembenihan ikan kerapu batik, Epinephelus microdon dimulai dengan percobaan pematangan gonad dan pemijahan. Untuk meningkatkan keragaan pemijahan dan kualitas telur telah dilakukan percobaan pemeliharaan induk ikan kerapu batik dalam 2 buah bak beton volume $30 \mathrm{~m}^{3}$. Setiap bak diisi 15 ekor induk ikan yang terdiri atas 10 ekor induk betina dengan bobot antara 2,2--4,0 kg dan 5 ekor induk jantan dengan bobot 2,3--3,5 kg. Ikan diberi pakan sekali setiap hari berupa campuran moist pellet, ikan rucah, curni, dan ditambah $3 \%$ lesitin (sebagai sumber fosfolipid) (perlakuan A) atau campuran moist pellet, ikan rucah, dan cumi tanpa ditambah lesitin (perlakuan B). Hasil percobaan menunjukkan populasi ikan yang diberi pakan tanpa ditambah fosfolipid memijah 11 kali dengan total telur mencapai 22.570.000 butir, dengan telur mengapung sebanyak $61,3 \%$. Sementara untuk populasi ikan yang diberi pakan dengan penambahan fosfolipid memijah 9 kali dengan total telur mencapai 39.773.000 butir, dengan telur mengapung mencapai $74,5 \%$. Daya tetas telur dan SAI (survival activity index) larva ikan yang diberi pakan dengan penambahan fosfolipid adalah berturut-turut $76,9 \%$ dan 7,73 ; lebih tinggi dibandingkan dengan yang tanpa diberi fosfolipid yaitu $67,8 \%$ dan 4,72. Kandungan fosfatidil kolin dan asam lemak DHA pada telur juga meningkat dengan penambahan fosfolipid pada pakan induk. Hasil percobaan menunjukkan bahwa penambahan fosfolipid dalam pakan induk dapat meningkatkan keragaan pemijahan dan kualitas telur serta larva ikan kerapu batik.
\end{abstract}

ABSTRACT: Role of dietary phospholipid on spawning and egg quality of marble grouper, Epinephelus microdon. By: Nyoman Adiasmara Giri, Tony Setiadharma, and Bejo Slamet

The experiment on the effect of dietary phospholipid on gonadal maturation and egg quality of marble grouper $\boldsymbol{E}$. microdon was conducted in 2 concrete tanks of $30 \mathrm{~m}^{3}$ volume. Ten female fish breeders of $2.2--4.0 \mathrm{~kg}$ body weight and five male fish breeders of 2.3--3.5 kg were reared in each tank. Fish were fed with experimental diets containing the mixtures of trash fish + squid + moist pellet + lecithin as phospholipid source (treatment A) or the mixture of trash fish + squid + moist pellet + without lecithin (treatment B). Results of the experiment showed that fish fed with diet without phospholipid supplementation spawned 11 times and produced totally 22,570,000 eggs, with $61.3 \%$ floating eggs. While fish fed with diet with phospholipid supplementation spawned 9 times and produced totally 39,773,000 eggs with $74.5 \%$ floating eggs. Egg quality indicated by hatching rate and SAl of larvae of fish fed phospholipid supplemental diet were $76.9 \%$ and 7.73 , respectively, which were higher than those of fish fed with diet without supplemental phospholipid (67.8\% and 4.72). Phosphatidylcholine and DHA contents of egg from fish fed phospholipid supplemental diet were higher than those of fish fed with diet without phospholipid supplementation. These data indicated that dietary phospholipid could improve spawning performance, egg, and larval quality of marbled grouper.

KEYWORDS: $\quad$ marble grouper, phospholipid, egg, larvae quality

\section{PENDAHULUAN}

Ikan kerapu batik (Epinephelus microdon) mempunyai nilai ekonomis penting dan merupakan komoditas ekspor. Hal ini mendorong usaha penangkapan di alam semakin meningkat yang mengakibatkan kelestariannya terganggu dan dapat

Peneliti pada Balai Besar Riset Perikanan Budidaya Laut, Gondol menyebabkan kerusakan lingkungan karang karena cara penangkapan yang kurang tepat seperti penggunaan obat bius (sianida). Penelitian pembenihan ikan kerapu ini telah dilakukan di Balai Besar Riset Perikanan Budidaya Laut, Gondol-Bali untuk mendapatkan teknologi produksi benih sehingga dapat diproduksi benih secara massal 
untuk keperluan budi daya maupun untuk restocking.

Kerapu batik telah dapat memijah dan menghasilkan telur yang dibuahi dalam bak terkontrol (Slamet \&Tridjoko, 1997; Giri et al., 1999). Keberhasilan pemijahan ini masih menemui beberapa masalah seperti tidak berlanjutnya proses kematangan gonad, pemijahan yang masih mengikuti musim, kualitas telur yang sangat bervariasi mengakibatkan banyak kegagalan dalam pemeliharaan larvanya. Hasil penelitian pada beberapa spesies ikan laut menunjukkan bahwa kualitas pakan induk sangat mempengaruhi proses pematangan gonad dan kualitas telur yang dihasilkan (Watanabe, 1988; Watanabe et al., 1984; Tandler et al., 1995). Proses pematangan gonad dan kualitas telur ikan kerapu batik meningkat dengan penambahan cumi segar pada pakannya. Sementara pemberian pakan yang ditambah minyak cumi meningkatkan kualitas telur yang dihasilkan (Giri et al., 1999). Penggunaan tepung cumi sebagai sumber protein pakan juga meningkatkan pemijahan dan kualitas telur yang dihasilkan (Giri et al., 2001a).

Fosfolipid merupakan bagian dari lipid yang banyak mengandung asam lemak tak jenuh (PUFAs). Hasil penelitian menunjukkan bahwa cadangan lipid pada telur ikan disimpan pada lipoprotein dari kuning telur yang terutama terdiri atas polar lipid, khususnya fosfatidil kolin (PC) dan fosfatidiletanolamin (PE) serta kaya akan n-3 HUFA (DHA) (Wiegand, 1996). Komposisi asam lemak dari PC, PE, dan PI (fosfatidil inositol) dari gonad dan telur ikan gilthead seabream (Sparus aurata) sangat dipengaruhi oleh kandungan lemak dan asam lemak dari pakan induk (Rodriguez et al., 1998). Gallagher et al. (1998) juga melaporkan PI merupakan fosfolipid dominan pada telur ikan striped bass (Morone saxatilis). Penelitian ini bertujuan untuk mengetahui peranan fosfolipid dalam pakan induk terhadap keragaan pemijahan, kualitas telur, dan larva ikan kerapu batik.

\section{BAHAN DAN METODE}

Sebagai wadah percobaan digunakan 2 buah bak beton volume $30 \mathrm{~m}^{3}$ yang masing-masing bak diisi 15 ekor ikan, terdiri atas 10 ekor induk betina dan 5 ekor induk jantan. Ikan dipelihara dengan sistem air mengalir dengan pergantian air mencapai 300\% per hari, dan dilengkapi dengan aerasi. Induk ikan diperoleh dari pengumpul ikan kerapu di Bali. Induk betina mempunyai ukuran bobot $2,2--4,0 \mathrm{~kg}$ dengan panjang total $41--54 \mathrm{~cm}$, dan induk jantan mempunyai bobot 2,3--3,5 kg dengan panjang 48--53 cm. Ikan diberi pakan berupa moist pellet (pelet basah) dengan sumber protein tepung ikan dan tepung cumi, serta ditambah $3 \%$ lesitin sebagai sumber fosfolipid (perlakuan A) atau tanpa ditambah lesitin (perlakuan
B). Moist pellet dimasukkan dalam ikan rucah saat pemberian pakan sehingga langsung dimakan oleh ikan. Di samping itu induk ikan juga diberi cumi segar. Komposisi proksimat pakan percobaan disajikan pada Tabel 1. Ikan diberi pakan sampai tidak mau makan (kenyang). Penelitian berlangsung selama 6 bulan.

Untuk mengetahui pengaruh fosfolipid pada keragaan pemijahan, maka saat terjadi pemijahan diamati beberapa parameter yang meliputi jumlah telur, kualitas telur (telur mengapung dan daya tetas telur), dan Survival Activity Index (SAI) sebagai parameter kualitas larva. Nilai SAI dihitung berdasarkan metode Kayano \& Mito (1993). Untuk mengetahui profil kelas lipid dan komposisi asam lemak pada telur akibat penambahan fosfolipid pada pakan induk dilakukan analisis kelas lipid dan komposisi asam lemak dari contoh telur yang dihasilkan. Polar lipid (PL) dan neutral lipid (NL) dipisahkan dengan kolom florisil. Selanjutnya masing-masing PL dan NL disuntikkan pada high performance liquid chromatography (HPLC) untuk mendapatkan komposisi kelas lipid (AOAC, 1995). Komposisi asam lemak dianalisis menggunakan gas kromatografi (GC) setelah dilakukan safonifikasi dan metilasi (Apriyantono et al., 1989). Analisis komposisi kelas lipid dan asam lemak dilakukan di Laboratorium Biokimia dan Enzimatik, Balai Penelitian Bioteknologi Tanaman Pangan, Bogor.

\section{HASIL DAN BAHASAN}

Selama periode percobaan (April s.d. Oktober 2002) telah terjadi 11 kali pemijahan untuk ikan yang diberi pakan tanpa penambahan fosfolipid dengan jumlah telur mencapai 22.570.000 butir atau 797.526 telur per kg induk betina. Dari jumlah tersebut diperoleh 13.830 .000 telur yang mengapung $(61,3 \%)$ dengan daya tetas rata-rata $67,8 \%$. Sementara itu pada ikan yang diberi pakan dengan penambahan fosfolipid memijah sebanyak 9 kali dengan jumlah telur jauh lebih banyak yaitu mencapai 39.773.000 butir atau 1.362.089 telur per kg induk betina. Dari jumlah tersebut diperoleh sebanyak 29.630.000 telur mengapung $(74,5 \%)$ dengan daya tetas mencapai 76,9\% (Tabel 2 dan Gambar 1).

Pemijahan terjadi pada bulan April, Mei, Juni, dan Juli dengan mengikuti siklus lunar, yaitu sekitar 3 hari menjelang dan 3 hari sesudah bulan baru. Pemijahan berhenti mulai bulan Agustus sampai Oktober. Pola waktu pemijahan yang sama juga terjadi pada tahun sebelumnya (Giri et al., 2001b).

Kualitas telur yang ditunjukkan oleh jumlah telur mengapung serta tingkat daya tetas telur dan kualitas larva (SAI) lebih tinggi pada induk ikan yang diberi tambahan fosfolipid pada pakannya (Tabel 2). Telur mengapung menunjukkan telur yang dibuahi 
Tabel 1. Komposisi pakan percobaan (\% bahan kering)

Table 1. Ingredient composition of the experimental diets (\% dry matter)

\begin{tabular}{|c|c|c|}
\hline \multirow{2}{*}{$\begin{array}{l}\text { Bahan } \\
\text { Ingredients }\end{array}$} & \multicolumn{2}{|c|}{ Pakan percobaan (Experimental diets) } \\
\hline & $\begin{array}{l}\text { Dengan fosfolipid } \\
\text { With phospholipid }\end{array}$ & $\begin{array}{c}\text { Tanpa fosfolipid } \\
\text { Without phospholipid }\end{array}$ \\
\hline Tepung ikan (Fish meal) & 53 & 53 \\
\hline Tepung hati cumi (Squid liver meal) & 20 & 20 \\
\hline Tepung kepala udang (Shrimp head meal) & 5 & 5 \\
\hline Tepung kedelai (Soybean meal) & 5 & 5 \\
\hline Campuran mineral (Mineral mix) ${ }^{1}$ & 2 & 2 \\
\hline Campuran vitamin $(\text { Vitamin mix })^{1}$ & 2 & 2 \\
\hline Minyak cumi (Squid oil) & 5 & 5 \\
\hline Minyak kedelai (Soybean oil) & - & 3 \\
\hline Lesitin kedelai (Soybean lecithin) ${ }^{2}$ & 3 & - \\
\hline Tepung terigu (Wheat flour) & 5 & 5 \\
\hline \multicolumn{3}{|l|}{ Komposisi nutrien (Nutrient composition, \% DM): } \\
\hline Protein (Protein) & 54.5 & 54.5 \\
\hline Lemak (Lipid) & 19.1 & 20.0 \\
\hline Abu $(A s h)$ & 12.4 & 12.1 \\
\hline \multicolumn{3}{|c|}{ 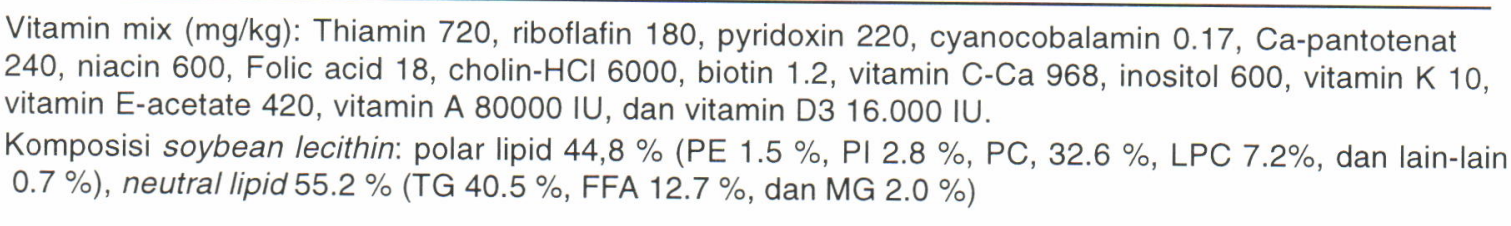 } \\
\hline
\end{tabular}

Tabel 2. Keragaan pemijahan induk ikan kerapu batik yang diberi pakan percobaan

Table 2. Spawning performance of marble grouper broodstock fed experimental diet

\begin{tabular}{|c|c|c|}
\hline \multirow{2}{*}{$\begin{array}{l}\text { Parameter } \\
\text { Parameters }\end{array}$} & \multicolumn{2}{|c|}{ Pakan percobaan (Experimental diet) } \\
\hline & $\begin{array}{l}\text { Dengan fosfolipid } \\
\text { With phospholipid }\end{array}$ & $\begin{array}{c}\text { Tanpa fosfolipid } \\
\text { Without phospholipid }\end{array}$ \\
\hline $\begin{array}{l}\text { Induk betina (Female breeder): } \\
\text { Jumlah (Number) pcs. } \\
\text { Bobot (Weight) kg. } \\
\text { Panjang total (Total length) Cm } \\
\text { Bobot total (Total weight) } \mathrm{kg}\end{array}$ & $\begin{array}{c}10 \\
2.4--4.0 \\
45--54 \\
29.2 \\
\end{array}$ & $\begin{array}{c}10 \\
2.2--3.5 \\
41--54 \\
28.3\end{array}$ \\
\hline $\begin{array}{l}\text { Induk Jantan (Male breeder): } \\
\text { Jumlah (Number) pcs } \\
\text { Bobot (Weight) kg } \\
\text { Panjang total (Total length), Cm } \\
\text { Bobot total (Total Weight) kg }\end{array}$ & $\begin{array}{c}5 \\
2.5-3.5 \\
48--53 \\
15.5 \\
\end{array}$ & $\begin{array}{c}5 \\
2.3-3.2 \\
48--52 \\
14.3\end{array}$ \\
\hline $\begin{array}{l}\text { Pemijahan (Spawning): } \\
\text { Frekuensi (Frequency) } \\
\text { Jumlah telur (No. of egg) } \\
\text { Jumlah telur/kg ikan (No. egg/kg of fish) } \\
\text { Jumlah telur mengapung (No. floating egg) } \\
\text { Diameter telur (Egg diameter) } \mathrm{mm} \\
\text { Diameter butir minyak (Diameter of oil globule) } \mathrm{mm} \\
\text { Daya tetas (Hatching rate) \% } \\
\text { SAl (Survival activity index) }\end{array}$ & $\begin{array}{c}9 \\
39,773,000 \\
1,362,089 \text { telur } \\
29,630,000(74.5 \%) \\
824 \pm 35 \\
207.6 \pm 0.8 \\
76.9 \pm 4.6 \\
7.73 \pm 1.15\end{array}$ & $\begin{array}{c}11 \\
22,570,000 \\
797,526 \text { telur } \\
13,830,000(61,3 \%) \\
825 \pm 27 \\
205.4 \pm 0.6 \\
67.8 \pm 5.2 \\
4.72 \pm 0.19 \\
\end{array}$ \\
\hline
\end{tabular}




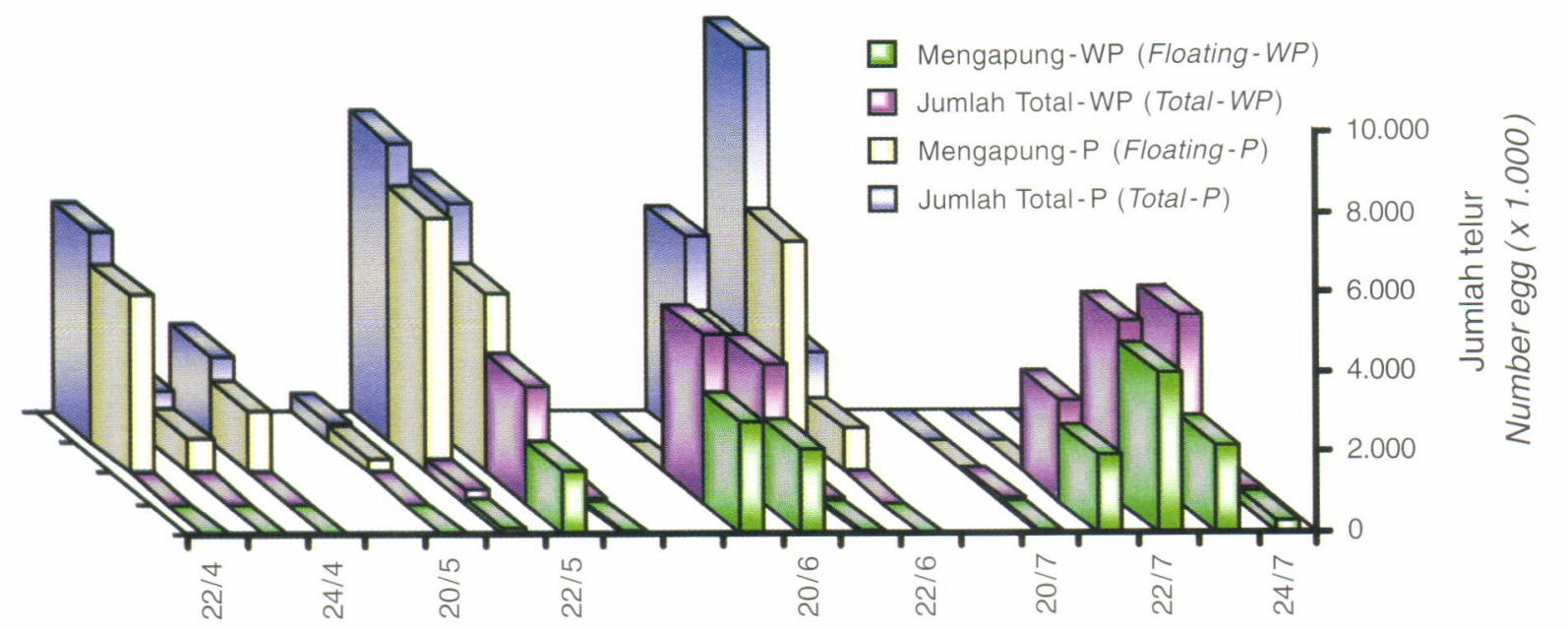

Tanggal memijah

Date of spawning

Gambar 1. Keragaan pemijahan dan jumlah telur kerapu batik yang diberi pakan percobaan

Figure 1. Spawning performance and egg number of marble grouper fed the experimental diet ( $W=$ without, $P=$ phospholipid)

sempurna dan mempunyai gelembung minyak yang sempurna. Sementara telur yang tidak dibuahi akan tenggelam. Daya tetas rata-rata telur ikan yang diberi pakan dengan penambahan fosfolipid mencapai $76,9 \%$; lebih tinggi dibandingkan dengan yang tanpa diberi pakan tambahan fosfolipid pada pakan induknya yaitu $67,8 \%$.

Demikian juga dengan nilai SAI larva dari induk yang diberi pakan dengan penambahan fosfolipid mencapai 7,73 dan larva bertahan hidup sampai hari ke-5 tanpa diberi pakan. Sementara SAI larva ikan dari induk yang diberi pakan tanpa penambahan fosfolipid hanya 4,72 dan larvanya hanya mampu bertahan hidup sampai hari ke-4. Data ini jelas menunjukkan adanya peningkatan kualitas telur yang dihasilkan dari induk yang diberi pakan dengan penambahan fosfolipid.

Wiegand (1996) melaporkan cadangan lipid pada telur ikan disimpan pada lipoprotein dari kuning telur yang sebagian besar terdiri atas PL, khususnya fosfatidil kolin (PC) dan fosfatidil etanolamin (PE). Fosfolipid yang digunakan pada percobaan ini berasal dari lesitin kedelai dengan komposisi 55,2\% netral lipid (NL) dan 44,8\% polar lipid (PL). Komponen terbesar dari NL adalah trigliserida (TG) yang mencapai 40,5\%; sementara komponen terbesar untuk PL-nya adalah fosfatidil kolin yang mencapai $32,6 \%$. Komposisi kelas lipid pada pakan percobaan dan pada telur ikan yang diberi pakan dengan kandungan fosfolipid berbeda tertera pada Tabel 3. Kandungan PE, PI, dan PC pada pakan yang diberi fosfolipid adalah lebih tinggi dibandingkan dengan yang tanpa penambahan fosfolipid. Digliserida (DG) dan TG pada NL pakan tanpa penambahan fosfolipid jauh lebih tinggi dibandingkan dengan yang ditambah fosfolipid. Hal ini karena adanya penambahan minyak kedelai sebanyak 3\% sebagai penyeimbang lesitin. Peningkatan kandungan $\mathrm{PI}$ dan $\mathrm{PC}$ dalam pakan induk, karena adanya penambahan fosfolipid mengakibatkan meningkatnya kandungan PI dan PC dalam telur yang dihasilkan. Kandungan PC meningkat hampir 4 kali dibandingkan dengan yang tanpa penambahan fosfolipid. Fosfatidil kolin ini merupakan cadangan lemak pada telur ikan seperti dilaporkan Wiegand (1996), yang selanjutnya akan dirombak dan dimanfaatkan pada stadia larva.

Lipid merupakan sumber energi pada fase embrio dan fase awal dari larva. Polar lipid (PL) mempunyai sifat antioksidasi walaupun PL mengandung lemak tak jenuh yang mudah teroksidasi (Ishihara, 1996). Fosfatidil Inositol (PI) dan asam lemak arachidonat dari fosfolipid mempunyai peran penting pada proses pembuahan dan perkembangan embrio, yang diamati pada ikan striped bass (Gallagher et al., 1998). Pickova et al. (1997) melaporkan kandungan arachidonat dan rasio DHA/EPA dari fraksi fosfolipid merupakan faktor penting yang menentukan viabilitas dari telur ikan cod (Gadus morhua). Setelah menetas dan sebelum makan, beberapa larva ikan laut menunjukkan kecenderungan untuk merombak PC dan sebaliknya menyintesis PE (Rainuzzo et al., 1997). Mekanisme seperti diuraikan di atas diduga juga terjadi pada percobaan induk kerapu batik, di mana penambahan fosfolipid pada pakannya 
Tabel 3. Komposisi kelas lipid pakan percobaan dan telur ikan yang diberi pakan percobaan (\% area)

Table 3. Lipid class composition of experimental diet and egg of marble grouper fed experimental diet (\% area)

\begin{tabular}{|c|c|c|c|c|c|}
\hline & \multicolumn{3}{|c|}{$\begin{array}{l}\text { Pakan percobaan } \\
\text { Experimental diet }\end{array}$} & \multicolumn{2}{|c|}{$\begin{array}{l}\text { Telur } \\
\text { Egg }\end{array}$} \\
\hline & $\begin{array}{l}\text { Dengan f } \\
\text { With phos }\end{array}$ & $\begin{array}{l}\text { sfolipid } \\
\text { holipid }\end{array}$ & $\begin{array}{c}\text { Tanpa fosfolipid } \\
\text { Without phospholipid }\end{array}$ & $\begin{array}{l}\text { Dengan fosfolipid } \\
\text { With phospholipid }\end{array}$ & $\begin{array}{c}\text { Tanpa fosfolipid } \\
\text { Without phospholipid }\end{array}$ \\
\hline \multicolumn{6}{|c|}{ 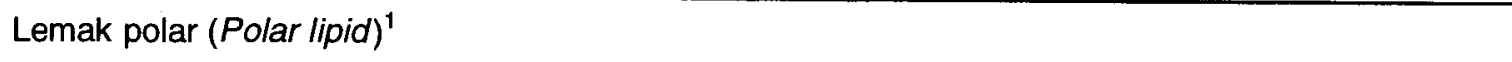 } \\
\hline PE & & 15.70 & 11.81 & 6.69 & 18.00 \\
\hline PS & & & 15.58 & 3.00 & 6.57 \\
\hline $\mathrm{PI}$ & & 30.11 & 16.84 & 35.76 & 30.71 \\
\hline LPE & & 19.15 & 7.53 & 13.08 & 8.68 \\
\hline PC & & 14.18 & 9.99 & 18.48 & 4.78 \\
\hline \multicolumn{6}{|c|}{ Lemak netral (Neutral lipid) ${ }^{1}$} \\
\hline TG & & 3.61 & 14.32 & 6.66 & 9.67 \\
\hline FFA & & 3.95 & - & - & 3.57 \\
\hline FS & & 4.59 & - & 6.20 & - \\
\hline DG & & 5.46 & 12.97 & 6.01 & 6.39 \\
\hline$M G$ & & - & 5.35 & - & 7.73 \\
\hline Lainny & a (Others) & 3.24 & 5.62 & 4.10 & 3.91 \\
\hline
\end{tabular}

'PS: fosfatidilserin (phosphotidih, LPE: lisofosfatidiletanolamin (lisophosphotidiletanolamin), FFA: asam lemak bebas (free fatty acio), FS: sterol bebas (free steron)

Tabel 4. Komposisi asam lemak pakan percobaan dan telur ikan kerapu batik yang diberi pakan percobaan (\% area)

Table 4. Fatty acids composition experimental diet and egg of marble grouper fed experimental diet (\% area)

\begin{tabular}{|c|c|c|c|c|}
\hline & \multicolumn{2}{|c|}{$\begin{array}{l}\text { Pakan percobaan } \\
\text { Experimental diet }\end{array}$} & \multicolumn{2}{|r|}{$\begin{array}{c}\text { Telur } \\
\text { Egg }\end{array}$} \\
\hline & $\begin{array}{l}\text { Dengan fosfolipid } \\
\text { With phospholipid }\end{array}$ & $\begin{array}{c}\text { Tanpa fosfolipid } \\
\text { Without phospholipid }\end{array}$ & $\begin{array}{l}\text { Dengan fosfolipid } \\
\text { With phospholipid }\end{array}$ & $\begin{array}{c}\text { Tanpa fosfolipid } \\
\text { Without phospholipid }\end{array}$ \\
\hline C. $14: 0$ & 3.48 & 4.77 & 4.25 & 2.67 \\
\hline C. $16: 0$ & 0.26 & 0.65 & 0.39 & 0.26 \\
\hline C. $18: 0$ & 0.48 & 0.91 & 1.03 & 0.70 \\
\hline C. $18: 1$ & 17.45 & 18.91 & 23.68 & 15.39 \\
\hline C. $18: 2 n-6$ & 5.09 & 6.48 & 7.97 & 5.93 \\
\hline C. $18: 3 n-6$ & 1.43 & 1.65 & 2.73 & 3.14 \\
\hline C. $18: 3 n-3$ & 1.37 & 1.47 & 2.18 & 3.21 \\
\hline C. $18: 4 n-3$ & 6.41 & 6.86 & 12.88 & 9.75 \\
\hline C. $20: 1 n-3$ & 16.18 & 19.81 & 18.62 & 12.78 \\
\hline C. $20: 4 n-6$ & 2.48 & 10.61 & 3.66 & 3.43 \\
\hline C. $20: 4 n-3$ & 5.20 & 2.22 & 1.15 & 0.89 \\
\hline C. $20: 5 n-3$ & 2.60 & 3.64 & 1.99 & 1.59 \\
\hline C.22:0 & 0.16 & 1.24 & 4.73 & 1.94 \\
\hline C. $22: 4 n-6$ & 4.10 & 1.13 & 1.02 & 0.23 \\
\hline C. $22: 5 n-6$ & 5.73 & 5.43 & 3.92 & 0.21 \\
\hline C. $22: 5 n-3$ & 0.71 & 2.40 & 2.14 & 3.29 \\
\hline C. $22: 6 n-3$ & 0.45 & 0.58 & 2.05 & 1.57 \\
\hline Total n-3 & 32.92 & 36.98 & 41.01 & 33.08 \\
\hline Total n-6 & 18.83 & 25.30 & 19.30 & 12.94 \\
\hline Total n-3 & 8.96 & 8.84 & 7.33 & 7.34 \\
\hline
\end{tabular}


menghasilkan telur dengan kandungan PC yang tinggi serta meningkatnya kualitas telur serta SAI larva yang dihasilkan.

Pada Tabel 4 terlihat kandungan asam lemak C18:1, lenoleat, EPA (eicosapentaenoic acid) dan DHA (doxosahexaenoic acid) adalah lebih tinggi pada telur ikan yang diberi pakan dengan penambahan fosfolipid. Total asam lemakn-3 pada pakan berasal dari minyak cumi, minyak kedelai dan juga lecitin. Sementara total asam lemak n-3 HUFA berasal dari minyak hewani (minyak cumi, tepung ikan, tepung hati cumi, dan tepung kepala udang), sehingga kandungan dalam pakannya hampir sama. Asam lemak EPA dan DHA ( $n-3$ HUFA) ini adalah esensial bagi larva ikan laut dan sangat menentukan sintasan larva (Watanabe, 1993; Webster \& Lovell, 1990). Kekurangan asam lemak n-3 HUFA pada larva ikan laut mengakibatkan tingkat kematian yang tinggi, pertumbuhan yang lambat, serta tidak sempurnanya pembentukan dan fungsi gelembung renang (Sorgeloos et al., 1988; Webster \& Lovell, 1990; Koven et al., 1990).

\section{KESIMPULAN}

- Penambahan fosfolipid dalam pakan induk ikan kerapu batik meningkatkan produksi telur, kualitas telur, dan kualitas larvanya.

- Kandungan fosfatidil kolin (PC) dan asam lemak DHA pada telur meningkat dengan penambahan fosfolipid pada pakan induk kerapu batik.

\section{DAFTAR PUSTAKA}

Apriyanto, A., D. Fardias, N.L. Puspitasari, Sedarnawati, dan S. Budiyanto. 1989. Petunjuk Laboratorium Analisis Pangan. IPB, Bogor. 180 pp.

Association of Official Analytical Chemists (AOAC). 1995. Official Methods of Analysis, $16^{\text {th }}$ eds. AOAC Inc. Arlington, Verginia, USA., 1,018 pp.

Gallagher, M.L., L. Paramore, D. Alves, and R.A. Rolifson. 1998. Comparison of phospholipid and fatty acid composition of wild and cultured striped bass eggs. J. Fish Biol., 52: 1,218--1,228.

Giri, N.A., B. Slamet, dan Tridjoko. 1999. Pematangan gonad dan pemijahan induk ikan kerapu batik, Epinephelus microdon dengan perbaikan mutu pakan. Dalam Sudradjat, A., E.S. Heruwati, J. Widodo, dan A. Poernomo (Eds.). Prosiding Seminar Nasional Penelitian dan Diseminasi Teknologi Budidaya Laut dan Pantai. Pusat Penelitian dan Pengembangan Perikanan. Jakarta., p.179--183.

Giri, N.A., Tony S., K.M. Setiawati, dan Wardoyo. 2001a. Pembenihan ikan kerapu batik, Epinephelus microdon: Spesies kandidat untuk menunjang pengembangan budidaya laut. Dalam Aliah, R.S., Herdis, D. Irawan, dan M. Surachman (Eds.).
Prosiding Lokakarya Nasional Pengembangan Agribisnis Kerapu. Pusat Pengkajian dan Penerapan Teknologi Budidaya Pertanian, Badan Pengkajian dan Penerapan Teknologi. Jakarta., p.157--165.

Giri, N.A., B. Slamet, T. Setiadharma, dan Basori. 2001b. Pengaruh sumber protein pakan induk terhadap perkembangan gonad dan kualitas telur ikan kerapu batik, Epinephelus microdon. In Sudradjat, A., E.S. Heruwati, A. Poernomo, A. Rukyani, J. Widodo, E. Danakusumah (Eds.). Teknologi Budidaya Laut dan Pengembangan Sea Farming di Indonesia. Pusat Penelitian dan Pengembangan Eksplorasi Laut dan Perikanan. Jakarta., p. 129--136.

Ishihara, K. 1996. Antioxidant mechanisms of phospholipid. Bull. Nat. Res. Inst. Fish. Sci. Japan., 8: 19-146.

Kayano, Y. and T. Mito. 1993. Effects of salinity on the embryonic development and larval survival of spotted grouper, Epinephelus akaara. Saibai Giken., 22: 35--38.

Koven, W.M., A. Tandler, G.W. Kissil, D. Sklan, O. Friezlander, and M. Harel. 1990. The effect of dietary (n-3) polyunsaturated fatty acids on growth, survival and swim bladder development in Sparus aurata larvae. Aquaculture., 91: 131--141.

Pickova, J., P.C. Dutta, P.O. Larsson, and A. Kiessling. 1997. Early embryonic cleavage pattern, hatching success, and egg-lipid fatty acid composition: Comparison between two cod (Gadus morhua) stocks. Can. J. Fish. Aquat. Sci., 54: 2,410--2,416.

Rainuzzo, J.R., K.I. Reitan, and Y. Olsen. 1997. The significance of lipid at early stages of marine fish: a review. Aquaculture., 155: 105--118.

Rodriguez, C., J.R. Cejas, M.V. Martin, P. Badia, M. Samper, and A. Lorenzo. 1998. Influence of $n-3$ highly unsaturated fatty acid deficiency on the lipid composition of broodstock gilthead seabream (Sparus aurata) and on egg quality. Fish Physiol. Biochem., 18: $177--187$.

Slamet, B. dan Tridjoko. 1997. Pengamatan pemijahan alami, perkembangan embrio, dan larva ikan kerapu batik, Epinephelus microdon dalam bak terkontrol. J. Pen. Per. Indonesia., 3 (4): 40--50.

Sorgeloos, P., P. Leger, and P. Lavens. 1988. Improved larval rearing of European and Asian seabass, seabream, mahi-mahi, siganid, and milkfish using enrichment diets for Brachionus and Artemia. World Aquacult., 19: 78--79.

Tandler, A., M. Harel, W.M. Koven, and S. Kolkovski. 1995. Broodstoock and larvae nutrition in gilthead seabream Sparus aurata new findings on its mode of involment in improving growth, survival, and swimblader inflation. Bamidgeh., 47: 95--111.

Watanabe, T. 1993. Importance of docosahexaenoic acid in marine larval fish. J. World Aquacult. Soc., 24: 152$-161$.

Watanabe, T., T. Arakawa, C. Kitajima, and S. Fujita. 1984. Effect of nutritional quality of broodstock diets on reproduction of red sea bream. Bull. Jpn. Soc. Sci. Fish., 50 (3): 495--501. 
Watanabe, T. 1988. Fish Nutrition and Mariculture. Japan International Cooperation Agency (JICA). Japan., $233 \mathrm{pp}$.

Webster, C.D. and R.T. Lovell. 1990. Response of striped bass larvae fed brine shrimp from different sources containing different fatty acid composition. Aquaculture., 90: 49--61.

Wiegand, M.D. 1996. Composition, accumulation and utilization of yolk lipids in teleost fish. Rev. Fish Biol. Fish., 6: 259--286. 